\title{
A Review on Cross Cultural Education throughout Europe: Identity Issues
}

\section{Meral ŞEKER*}

\author{
Alanya Alaaddin Keykubat Üniversitesi, Eğitim Fakültesi, Antalya/Türkiye
}

CrossMark

\section{Article Info}

DOI: $10.14812 /$ cuefd.389797

Article history:

Received 03.02.2018

Revised 01.03.2018

Accepted 05.03.2018

Keywords:

Exchange programs,

Intercultural education,

Identity issues

\begin{abstract}
The past few decades have witnessed an increase in global mobility and an unprecedented number of exchange programs offered by various institutions and governments to enable students to receive education in foreign countries. The increase in the enrolment rates of international and exchange students has led many countries to reform their educational systems at curricular and practical levels to meet the needs of international students. European Council (2001), for instance, has developed a common framework of reference to enable students across Europe to travel for education with the hope of creating a common European identity. However, institutional reports and research findings show that in spite of the increasing opportunities and attempts to improve information and funding services to accommodate the needs of international students, the effectiveness of cross cultural education can be questioned. Among these predicaments, identity issues have been frequently reported (e.g., Andrade, 2006; Ho, 2009; Kuhn, 2012; Kim, 2014). In this respect, the present study aims to provide a review of recent studies and reports by focusing specifically on identity problems encountered by exchange students. The discussions presented and their implications are meant to contribute to improving the educational contexts for exchange students.
\end{abstract}

\section{Avrupa'da Kültürler Arası Eğitim üzerine bir İnceleme: Kimlik Sorunları}

\section{Makale Bilgisi}

DOI: $10.14812 /$ cuefd. 389797

Makale Geçmişi:

Geliş 03.02.2018

Düzeltme 01.03.2018

Kabul 05.03.2018

Anahtar Kelimeler:

Değişim programları,

Kültürlerarası eğitim,

Kimlik sorunları

\section{Öz}

Son yıllarda, küresel hareketlilik ve öğrencilere yönelik farklı kurumların sunduğu yurtdışı eğitim programlarının sayııında önemli derecede bir artış yaşanmıştır. Uluslararası eğitim ve değişim programlarına talepteki bu artış, birçok ülkenin, yabancı uyruklu öğrencilerin ihtiyaçlarına cevap verebilmek için eğitim sistemlerinde müfredat ve eğitim programlarını da içeren kapsamlı düzenlemelere gitmesine neden olmuştur. Örneğin, Avrupa Komisyonu (2001), ortak bir Avrupa kimliğine sahip olabilmelerini ve öğrencilerin Avrupa ülkelerinde eğitim almalarını kolaylaştırmak üzere Avrupa Ortak Ölçüt Çerçevesini sunmuştur. Ancak, artan olanaklara ve uluslararası öğrencilerin bilgi edinimi ve maddi olanaklar konularındaki intiyaçlarıı karşılama girişimlerindeki artışlara rağmen, araştırma sonuçları ve kurumsal raporlar öğrenci değişim programlarının etkinliğini sorgulayan bulgular içermektedir. Araştırma sonuçlarında sıkça ortaya konulan problemlerden biri, değişim öğrencilerinin yaşadığı kimlik sorunlarıdır (Andrade, 2006; Ho, 2009; Kuhn, 2012; Kim, 2014). Bu bağlamda, bu çalışma değişim programlarında eğitim alan öğrencilerin kimlik ile ilgili yaşadı̆̆ı problemleri ortaya koymak üzere alan yazındaki bulguları incelemeyi amaçlamaktadır. Bu bulgular özetlenerek, çalışmaların ortaya koyduğu kimlik problemleri tartışılmış ve sunulan önerilerle değişim programlarından faydalanan öğrencilerin koşullarının geliştirilmesine katkı sağlanacağı düşünülmüştür.

Author:meral.seker@alanya.edu.tr 


\section{Introduction}

The last century has witnessed a fast and a fundamental shift from the traditional inside-borders social, political and economic systems toward a global frame that is formed of beyond-borders powers and that functions inter-dependent of its international components. The new global formation of systems has required layers of societies such as economic, social, political, or cultural structures to be re-shaped accommodating for cross-borders activities and mobility. Along with the adaptation of structural and legislative regulations complying with cross-border systems, nations have also urged for creating cross-border cultures and identities. In this respect, intercultural understanding has emerged as a vital tool that can guide and enhance smooth transitions. As one of the most efficient ways to promote intercultural understanding, people mobility is viewed as a tool that enables individuals to gain firsthand experience and interaction with other nations, leading subsequently to understanding of diversity and global scale issues. Peterson et al. (1999) refer to the critical role of intercultural learning in creating a common global humanity. They state that intercultural learning could be a beacon, illuminating a world of cultural differences and a common global humanity, building blocks for a just and peaceful world' (p.76).

Education in general has been the most powerful tool in shaping social (mainly national) identities of young generations in almost every nation. Nations' histories show that political or military figures in the history stressed the importance of education in schools not only for transferring knowledge but also for creating national identities. Napoleon's famous quote (in Reisner, 1922) indicates the role played by national education: 'If the child is not taught from infancy that he ought to be a republican or a monarchist, a Catholic or a free-thinker, the state will not constitute a nation; it will rest on uncertain and shifting foundations; and it will be constantly exposed to disorder and change' (p.35). The history of nations shows similar quotes indicating the importance given to education in the formation of national identities (see e.g. for France: Weber, 1976; for Germany: Fichte, 1968; for Italy: Alesina\& FuchsSchundeln, 2005). Yet, although education is still an efficient way in shaping individuals' identities, the structural frames of the social identity that nations opt for today have changed dramatically. Today, the ultimate goals of nations should not be to have the young generations possess strong national identities, but in contrast, to have a generation with broader social identity that conveys understanding and tolerance of global cultures, openness and flexibility for adaptation in various social contexts, and eventually economic and political contributions to global systems beyond borders.

21st century requires nations to function internationally in political, economic, and thus cultural scales. Acting globally also brings the necessity for people's mobility. Although travelling across borders was done for mostly trade or business reasons at the beginning of the century, today, travelling for educational purposes is one of the most frequent reasons for people's mobility. The rate of students' mobility for education increased from 2 million in 2000 to over 4 million in 2012. International students comprised $1.8 \%$ of all tertiary enrolments globally (UNESCO, 2014). According to the statistics provided by UNESCO (2014), the majority of educational mobility is toward five countries comprising over half of the international students. These countries are USA hosting $18 \%$, UK hosting $11 \%$, France $7 \%$, Australia $6 \%$, and Germany with $5 \%$ of the total international student enrolment.

The increased number of international students brings along numerous benefits to the countries they study and live in. They establish business connections (NAFSA, 2003), develop international and foreign policy interests and become political allies (Schneider, 2000), or contribute to the country's economy by staying in the country after completing education and providing their skills in filling vacant positions (Colebatch, 2005). In addition to cultural, professional, and political benefits; international students also provide economic benefits to the foreign country they live in. For example, the revenue gained from international students in USA in 2013 was $\$ 22.7$ billion, over $€ 5$ billion in UK, and over $€ 10$ billion across Europe. Considering these economic contributions of international students, it is not surprising that countries have been promoting various programs to attract increased numbers of international students. Many of them have simplified their visa application processes, launched standardised educational programs and degree criteria, increased funding for distance and international 
education programs and widened their marketing schemes to reach out higher number of international students (Andrade, 2006; Coley, 1999; Lee and Wesche, 2000; Marshall, 2005).

In order to create cross-culturally competent young generations, nations should provide support in various contexts for students such as encouraging interaction between international and local students (Zhao et al., 2005), providing sufficient information services and appropriate education programs to ensure that students are satisfied with their experiences and return home with the desired attitudes and feelings (Carr et al., 1999). However, institutional reports and research findings show that in spite of the increasing opportunities and demands, the effectiveness of multicultural and cross cultural education is still questioned. Although there have been attempts to improve information and funding services and to modify educational approaches and practices to accommodate the needs of international students in the global scale, students still experience a large number of difficulties in their cross cultural education experiences. Among these predicaments, linguistic and identity issues have been reported as two of the most frequent ones (e.g., Andrade, 2006; Ho, 2009; Kuhn, 2012; Kim, 2014). Language barrier, usually lack of English proficiency, causes obstacles in international students' academic activities (Ramburuth, 2001, Ramsay et al., 1999, Trice, 2003). International students experience difficulties in following professors' lectures, in writing assignments, and in oral participation to the lessons (Jacob \&Greggo, 2001; Lee, 1997; Lewthwaite, 1996; Ramburuth, 2001; Trice, 2003). These language related obstacles create lack of confidence, increased anxiety for academic success, failure to access available help and withdrawal from social activities with local students (Mendelsohn, 2002; Robertson et al., 2000; Sarkodie-Mensah, 1998; Tompson\&Tompson, 1996). Studies also report that professors who have international students in their classes do not completely recognize the different learning styles, personalities and identities that these students possess (Robertson et al., 2000). As another frequently reported difficulty of international students, identity related issues still await solutions. To promote intercultural understanding among international students, students' multiple identities such as gender, race and ethnicity, country of origin, age, or linguistic background need to be acknowledged. Not being able to adjust their teaching styles and to attend to the special needs of these students, professors are usually reported to be indifferent by international students.

Overall, the studies indicate the need for bilateral adjustments by both professors and international students to increase the productivity of cross-border education experiences. In these adjustment processes, international students' personal and social identities should be considered as important factors in order to ensure successful adaptation. Cross-cultural education can promote a global common social identity; however, there is a need to further analyze identity issues in cross-cultural education.

\section{Aim of the Study}

The present study aims to provide a review on the current situation of exchange students in Europe and on the problems encountered during their experiences in the host countries while focusing specifically on the identity issues faced by Turkish exchange students.

\section{Method}

The study reports the findings gathered by following document analysis technique (Neuendorf, 2002). The results of recent studies and reports were reviewed by focusing specifically on identity problems encountered by Turkish exchange students. The discussions presented on the light of the review are meant to contribute to improving the educational contexts for exchange students.

\section{Common European Identity}

Creating a common European identity has been one of the main aims of European Union. One of the reasons for this goal is to increase EU's legitimacy. EU is indirectly legitimated by its member states where it has legislative power. However, this indirect legitimacy is found to be insufficient by many scholars (Decker, 2011; Habermas, 2001; Mather, 2006). The integration of Europe would not be possible only by economic transactions or legislation. Such an attempt would require bottom-up integration via social interactions of persons and create a common European identity. However, a great 
amount of research has established that social contacts for limited time and context (i.e., touristic visits, business trips) do not provide fruitful opportunities for integration (Feldstein, 1967; Puchala, 1981). Although such social contacts create networks of social transactions and may enhance cultural awareness and tolerance, they do not necessarily lead to formation of a common identity. For instance, Feldstein (1967) noted that vast labor migrations across Europe in 1960s failed to create favorable conditions to create a European identity in many cases. Even though immigrations introduced a new culture, a new language, and a work atmosphere in the hosting country, the majority of immigrants led a closed life within their minority groups and avoided, even resisted, full social integration. Thus, a collective European identity should go beyond limited social or economic transactions since the concept of 'identity' is not a static or concrete phenomenon. Rather, identity is a multi-layered, multidimensional and continuously evolving component of a social being.

As the largest exchange program in Europe, European Action Scheme for the Mobility of University Students (Erasmus) program was initiated to promote Europe's common identity. Over two million students have visited and studied in a foreign country with this program. The program was initiated in 1987 by European Union (EU) to enable students experience studying abroad while learning European countries' cultures. It was launched as a university student exchange program that organized and funded students to study in universities across Europe while European Court of Justice made diploma recognition and compatible student tuition fees possible within European countries (Sigalas, 2009). By 1995, Erasmus program was merged with other educational cross-border programs under Socrates (European Press Releases, 2006). Erasmus is part of the 'Lifelong Learning Program' (LLP) and promotes cross-cultural education for around three million students and teachers across 27 European Member countries along with Turkey, Norway, Iceland, and Liechtenstein (European Press Releases, 2006). LLP has been serving the mobility programs such as Comenius for schools, Erasmus for higher education, Leonardo da Vinci for vocational education and training, Gruntvig for adult education since 2007 (European Commission, 2007). Today, the activities of LLP continue under the new Erasmus Plus program for the years 2014-2020. The countries eligible to participate in this program are 27 EU countries plus EEA/EFTA Countries, Croatia, Turkey and Macedonia. Despite the structural changes at the institutional level, the official objectives of the program explained in the Council Decision of 1987 are still considered to be the framework:

The objectives of the Erasmus program are as follows: (i) to achieve significant increase in the number of students... spending an integrated period of study in another Member state, in order that the Community may draw upon an adequate pool of manpower with first-hand experience of economic and social aspects of other Member States ... ; (iv) to strengthen the interaction between citizens in different Member States with a view to consolidating the concept of a People's Europe; $(v)$ to ensure the developments of a pool of graduates with direct experience of intra-Community cooperation, thereby creating the basis upon which intensified cooperation in the economic and social sectors can develop at the Community level (European Press Releases, 2006).

The ultimate goal in promoting Erasmus is to increase personal contact among young adults on the way to create a supranational European identity. The Commission expected to create the European identity from below by enabling cross-border personal, social and educational contact among university students. Nevertheless, studies conducted with Erasmus exchange students report significant social and academic problems that may hinder cross cultural communication and understanding.

\section{Identity issues encountered by exchange students}

In its broader sense, social identity is defined by Tajfel (1978) as 'the part of an individual's selfconcept which derives from its knowledge of his membership of a social group (or groups) together with the value and emotional significance to that membership' (p.63). In order to understand identity formation and transformation, the complex facets of identity should be analyzed. Among the various theoretical distinctions made in social psychology to decipher identity, the foremost distinction is stated between personal and social identities. Tajfel (1981) defines personal identity as the combination of all psychological traits and dispositions that create personal uniqueness. Deriving from intrapsychic 
stimulants such as loving or mating, personal identities go through a formation process starting within families and are shaped by the linguistic, cultural, social and political-historical features of their specific contexts (Hurtado \& Silva, 2008). As a result of the impacts of these features, an individual develops 'me-ness', which is both unique because of the intrapsychic stimulants specific to the individual and common because of comprising universal processes of human beings.

According to the objectives, Erasmus has been promoted not only for educational purposes but also to enhance European countries' integration and to create a common European identity among younger generations. However, many scholars have warned against oversimplifying the concept of identity and overlooking to various factors influencing identity formation (Green, 2007; Marks, 1999). The reports by various institutions and research findings have emphasized the complexity of identity formation process and indicated that the challenges faced by exchange students can hinder such a transformation. The majority of the studies conducted on the impacts of cross-cultural education in Europe on the exchange students' identities have highlighted the challenges faced during this experience. For example, researchers have found that students go through identity confusion during their visits in the hosting country mainly since they have difficulty in adapting to social life (Kim, 2001; Ward, 2004). The difficulty for social adaptation and integration can result from financial problems (Yucesin-Tas, 2013); lack of foreign language knowledge (Groux\&Porcher, 2000); lack of collective self-esteem (Brown, 2008; Giddens, 1991); or negative reaction or discrimination by the hosting social environment (Brown, 2009; Stephan \& Stephan, 2001). Researchers have also stressed the link between geopolitical tensions in macro/global level and the micro context (Althen, 1994; Brown, 2009; Giddins, 1991; Ward, 2004). Contemporary socio-political developments in the global scale affect attitudes of societies in micro contexts. For instance, the recent rise in fundamentalist terrorist attacks (e.g. September 11 in USA) has given rise to 'islamophobia' in the western world. As a result of this tendency, as European Commission Against Racism and Intolerance (2010) reports, there has been an incline in negative reactions toward exchange students especially from Islamic countries. Brown (2009) also notes an increase in attacks against Muslim exchange students in the UK. Similarly, a tendency of decline in the number of international students has been reported for USA due to the prejudice and the discrimination against international students from Muslim countries of origin (Lee \& Rice, 2007).

In the context of Turkish exchange students, the majority of the studies conducted have focused on academic or language issues (e.g., Aba, 2013; Bakioglu\&Certel, 2010; Duru\&Poyrazli, 2007; Işık, 2011, Kaypak\&Ortactepe, 2014, etc.). Limited in number, the studies conducted with Turkish Erasmus students to find out the program's cultural or personal impacts have mostly reported issues related to cultural adaptation (e.g., Penbek, Yurdakul, \&Cerit 2012) or challenges regarding attitudes and identity (e.g. Başaran, 2010; Cısdık, 2014; Ersoy\&Günel, 2011; Şahin, 2008). Decreasing motivation due to the lack of contact with the hosting community (Cisdik, 2014), teachers' attitudes toward exchange students (Başaran, 2010) and cultural bias toward exchange students (Endes, 2015; Yildirim\&llin, 2013) have been found to lead Turkish Erasmus students to become more instrumentally motivated rather than becoming more willing to learn about European cultures. Yildirim and Ilin (2013), for example, have concluded in their study with Turkish Erasmus students that "the students' "psychological well-being" seems to be threatened by the negative impact of a continuous struggle against the bias toward their home culture" (p. 119). Endes (2015) explored Erasmus Program experiences of Turkish students focusing on not only academic but also personal and social issues encountered. As a result of the findings, she states that although most of the students reported no adaptation problems in their hosting countries, still a significant number of students (33\%) indicated adaptation problems. For these students, the discrimination and the negative attitudes toward them made their adaptation difficult. According to the responds of the students, religious issues affected the perception of the staff and they felt either ignored or not respected. As Endes puts it, "...some academic staff and teachers treat Erasmus students with cultural prejudice, discriminate during lessons, [and] exhibit negative behavior" (p. 1413). Another study focusing on Turkish exchange students' intercultural engagement in Europe, conducted by Kagitcibasi, Kisbu-Sakarya, and Aydogdu (2017), indicates that European students' initial evaluation of the visitor students from Turkey was mostly negative. While the reason for this attitude 
was not investigated in the study, the authors advise that orientation programs to support and to inform students in both countries are crucial to increase the opportunity for a successful positive cultural interaction and to decrease the possibility of cultural conflicts.

In order for exchange students across Europe to create a common European identity, they need to be open to intergroup communication. When they see themselves as 'national ambassadors' against attacks to their home country, their openness to interaction and tolerance will decrease while their patriotic feelings will be induced (Ward, 2004). Brown and Aktaş (2012) state that 'identity only assumes importance when it is challenged: no thoughts are given to identity when "belonging" comes naturally, when it does not need to be fought for, earned, claimed and defended' (p.5). Branscombe and Wann (1994) indicate that a strong cultural identity creates resistance when challenged and the individual or the group under perceived attack withdraws from any intergroup communication that would potentially lead to cross cultural understanding. Therefore, it is vital to acknowledge the identity issues among exchange students and to assist them in overcoming challenges and in developing a more open mind set.

\section{Discussion \& Conclusion}

European Commission Education and Training Division (2008) notes that the number of students who travel for education across Europe has increased significantly. The increase in demand, especially for higher education, has brought significant benefits to the hosting countries (Andrade, 2006) as well as additional problems (Fligstein, 2008; Risse, 2010). This increase may indicate that Erasmus exchange program has achieved its goal quantitatively. However, qualitative goals such as encouraging cultural awareness, being able to navigate professionally and personally across cultures, developing a European 'we-ness' has yet to be fully achieved. In case of Turkish students involved in exchange programs, the problems include language barrier, difficulties in academic adaptation, challenges in social and cultural adaptation as well as identity issues triggered mostly by negative attitudes or prejudiced behaviours in the hosting countries (Cetinkaya-Yildiz, Cakir\&Kondakcl, 2011; Isık, 2011; Endes, 2015).

In order to develop a common European identity, the young generation needs to have positive feelings about other cultural groups and a willingness to create cross-cultural relationships. Although cross-cultural education in a foreign country can provide the context for such an awareness, it would be too optimistic to expect that other contextual intervening factors will not hinder this process. Therefore, initiations of orientation programs like PLOTEUS (Portal on Learning Opportunities throughout the European Space) need to be increased. Programs to assist and guide exchange students at personal and social levels need to be considered as main components of the international education programs rather than focusing solely on educational and professional experiences.

Alternative means to enhance cultural awareness need to be found and the responsibility should be shared by all parties involved. This would include both the hosting country, i.e. hosting institutions, instructors, students, local citizens and administrative authorities, and the visitor side, i.e. visitor institutions, coordinators, exchange students, and administrative authorities. Erasmus Coordination Offices could be in constant contact with the offices and the academic staff in the hosting countries in order to both follow the students' academic progress closely and communicate with the staff on the students' personal well-being. However, as Endes (2015) also suggests, in case that such a negotiation procedure is not welcome by the hosting institution or stuff or in case the negative attitude against exchange students persists, then the renewal of the exchange program agreement with this institution should be re-considered in the following academic years. Cultural training previous to students' visit can be provided to students, instructors, and administrators from both sides. For outgoing Turkish students, an intensive orientation program should be developed and implemented. The orientation program need not only to familiarize students with the academic and institutional procedures of the hosting countries, but also to equip students with necessary communication skills to enable them voice and enquire about problems they encounter. When students are aware of their rights and their responsibilities and when they are capable of negotiating these rights and responsibilities, they could become more interculturally competent, which is a key tool for mutual understanding (Aba, 2016) and conflict resolution. The 
orientation programs should also include guidance sessions for daily practicalities such as housing or shopping to further decrease distress of sojourn students (Cetinkaya-Yildiz, Cakir\&Kondakcl, 2011). To decrease the financial limitations, today's advanced technology can be used to deliver such trainings. Emails, text messages, online social network sites can be used or online publications or platforms can be designed to deliver information about both countries' histories, values, norms, traditions, educational systems, or any other relevant aspects. Also, organizing face-to-face seminars or symposiums in both countries involved in an exchange program previous and during students' visits can be helpful in exchanging cultural expectations, creating a rapport and trust between cultures. When both exchange and hosting students are open and flexible to communicate and develop a positive relationship, it will draw Europe closer to the possibility of creating a generation with a strong European identity and crosscultural competences.

\section{Acknowledgements}

The English version of the paper was presented at 2nd International Academic Research Congress (INES) 2017 and the abstract was published in INES Abstract Proceedings. 


\section{Türkçe Sürümü}

\section{Giriş}

Geçtiğimiz yüzyıl, geleneksel sınırlar içi sosyal, politik ve ekonomik sistemlerden, sınırlar ötesi güçlerin dengelediği ve birbirini etkilediği küresel bir çerçeveye hızlı ve köklü geçişlere sahne olmuştur. $\mathrm{Bu}$ yeni küresel düzen, ulusların sınırlar ötesi hareketlilik ve etkinliklere olanak tanıyacak sosyal, ekonomik, politik veya kültürel yapılarında kapsamlı değişiklikler yapmasına neden olmuştur. Bu bağlamda, ulusların, sınırlar ötesi etkileşime olanak sağlayacak yapısal ve yasal değişimlerin yanında; sınırlar ötesi kültürler ve yeni kimlikler yaratılmasını teşvik edecek düzenlemeler yapması gerekmiştir. Bu gereksinim, kültürler arası hoşgörü ve etkileşimin önemini ortaya çıkarmış ve bunu sağlayacak en güçlü aracın insanların sınırlar ötesi hareketlilik olduğu ve bu deneyimlerin getireceği küresel bakış açısı ile çeşitliliğe dair olumlu tutumlar yaratılabileceği öne sürülmüştür Peterson vd. (1999; p.76) küresel toplum yaratmada kültürlerarası etkileşimin önemini vurgularken "kültürlerarası etkileşim, kültürel farklılıkların önemini ortaya çıkaran ve küresel insanlığı vurgulayan, küresel adalet ve barışı sağlama yolunda atılacak en güçlü adımlardandır" ifadesini kullanmışlardır.

Eğitim, şüphesiz her ulusun kendi sosyal kimliğini yeni nesillere aktarmasında en güçlü arç olmuştur. Ulusların tarihleri incelendiğinde, önemli politik veya askeri figürlerin okulun sadece bilgi aktaran kurumlar değil, aynı zamanda ulusal bir kimlik oluşturmadaki önemli rolünden bahsettikleri görülür. Napolyon'un şu ünlü sözü, eğitimin ulusal kimliğin oluşmasındaki rolünü gösterir: “Eğer bir çocuğa bebekliğinden itibaren bir cumhuriyetçi veya bir monarşi yanlısı, ya da bir Katolik yahut bir bağımsız düşünen bir birey olacağı öğretilmezse, o zaman o toplum bir ulus haline gelemeyecek; belirsiz ve sürekli değişen temeller üzerinde durmaya çalışacak ve her daim anarşiye ve değişimlere karşı savunmasız kalacaktır (bkz. Reisner, 1922, s. 35). Farklı uluslardan ünlü kişilerin eğitimin ulusal kimlik oluşturmadaki önemine dair bu tür sözlerine tarih boyunca rastlanmıştır (Bkz. Fransa için: Weber, 1976; Almanya için: Fichte, 1968; İtalya için: Alesina \& Fuchs-Schundeln, 2005). Her ne kadar eğitim ve onu sağlayan kurumlar ulusal veya sosyal kimlik oluşturmada önemli bir yere sahipse de, günümüzün değişen ve çok katmanlı toplumlarında ulusların amaçladığı sosyal kimlik kavramı da önemli değişimler göstermiştir. Günümüz toplumları, genç nesillerin katı bir ulus kimliği kazanması yerine; küresel kültürlerin bilincinde ve bunlara hoşgörü ile yaklaşan; farklılıklara açık ve uyumlu daha geniş bir sosyal kimlik edinmelerini ve sonuçta küreselleşen dünyada daha etkin sınırlar ötesi politik ve ekonomik katkılar sağlamalarını amaçlamaktadırlar.

21. yüzyıl, ulusların politik, ekonomik ve kültürel alanlarda uluslararası işlevler gerçekleştirmelerini gerektirmektedir. Ekonomik, politik ve kültürel anlamlarda küresellik ancak küresel hareketlilik ile gerçekleştirilebilir. Yüzyılın başında sınırlar arası seyahatlerin çoğunluğu ticaret veya iş gibi nedenlerle yapılmış olsa da, bugün eğitim amaçlı seyahatler çok yüksek seviyelerdedir. 2012 verilerine göre, öğrencilerin uluslarası hareketliliği 2000 yılındaki 2 milyondan, 4 milyona arttığını ve eğitim kurumlarına kayıtlı uluslararası öğrencilerin toplam öğrenci sayısının \% 1.8'ine denk geldiğini göstermektedir. (UNESCO, 2014). UNESCO'nun (2014) raporuna göre, dünyada en çok uluslararası öğrenciye sahip beş ülke toplam uluslararası öğrenci sayısının yarısına eğitim vermektedir. Bu ülkeler ve uluslararası öğrenci seviyeleri şöyledir: \% 18 ile Amerika, \%11 ile İngiltere, \% 7 ile Fransa, \% 6 ile Avustralya ve \% 5 ile Almanya'dır.

Artan uluslararası öğrenci sayısı ev sahibi ülkelere sayısız faydalar sağlamaktadır. Bu öğrenciler iş ağları oluşturma (NAFSA, 2003), uluslararası ve dış politikalar üretmede ve iyi ilişkiler kurmada köprü oluşturmakta (Schneider, 2000), veya eğitimlerini tamamladıktan sonra da bu ülkelerde kalıp çalışarak ülkenin ekonomisine katkılar sunmaktadırlar (Colebatch, 2005). Bu tür kültürel, politik ve ekonomik yararların yanında, eğitimleri boyunca da ev sahibi ülkedeki ihtiyaçlarını karşılarken ekonomik olarak katkı sağlamaktadırlar. Örneğin, uluslararası öğrencilerden elde edilen gelir 2013 yılında Amerika için 22.7 milyar Dolar, İngiltere için 5 milyar Pound ve Avrupa genelinde 10 milyar Euro olarak kaydedilmiştir. 
Bu gelirler göz önünde bulundurulduğunda, ülkelerin uluslararası öğrencileri çekmek için farklı programlar sunmaları şaşırtıcı değildir. Birçok ülke öğrenciler için vize uygulamalarında kolaylıklar tanıyan uygulamalara geçmiş ve eğitim harçlarında kayda değer indirimler getirmiştir (Andrade, 2006; Coley, 1999; Lee, 1997; Marshall, 2005).

Yurtdışındaki eğitim ve sosyal deneyimlerinden memnun, kültürler arası iletişim becerilerini geliştirebilmiş ve farklı bağlamlarda kültürel çeşitliliğe sahip çıkabilen nesiller yetiştirmek oldukça zor ve karmaşık bir süreç gerektirmektedir (Carr vd., 1999; Zhao vd., 2005). Ancak, bu konudaki araştırmalar ve raporlar, artan olanaklara ve gösterilen çabalara rağmen uluslararası eğitim programlarının etkinliğinin sorgulanması gerektiğine işaret etmektedir. Her ne kadar uluslararası öğrencilerin bilgi ve maddi olanaklarının arttırılmasına ve ulusal eğitim sistemlerinin yabancı uyruklu öğrencilere cevap verebilmek üzere yeniden yapılandırılmasına çalışııı̧ olsa da, bugün yabancı uyruklu öğrenciler gittikleri ülkelerde hala birçok problemle karşı karşıya kalmaktadır. Bu problemlerden en çok vurgulananlar öğrencilerin dil açısından yaşadıkları problemler ve kimlik sorunlarıdır (Andrade, 2006; Ho, 2009; Kuhn, 2012; Kim, 2014). Dil bariyeri, ki genelde İngilizce yetkinliğindeki eksiklikler, öğrencilerin akademik yaşamlarında sorunlar ve zorluklar yaşamasına neden olmaktadır (Ramburuth, 2001, Ramsay vd., 1999, Trice, 2003). $\mathrm{Bu}$ öğrenciler, öğretmenlerin derslerini takip etmede, ödevlerini yazmada ve sınıf içinde aktif olarak derslere katılmada (Jacob\&Greggo, 2001; Lee, 1997; Lewthwaite, 1996; Ramburuth, 2001; Trice, 2003) zorluklar yaşamaktadır. Bu tür zorluklar öğrencilerde öz-güven eksikliğine yol açabilmekte, endişe seviyelerini arttırmakta ve böylece yerel öğrencilerle etkileşimden geri durarak alabilecekleri yardımdan vazgeçmeye yol açabilmektedir (Mendelsohn, 2002; Robertson vd., 2000; Sarkodie-Mensah, 1998; Tompson \& Tompson, 1996). Çalışmalar aynı zamanda öğretmenlerin genelde sınıflarında yabancı uyruklu öğrencilerin olduğunu fark etmediklerini veya bu öğrencileri de kapsayacak ders uygulamaları yapmadıklarını göstermektedir (Robertson vd., 2000). Kimlik ile ilgili yaşanan sorunlar ise diğer sıklıkla ifade edilen problem olarak karşımıza çıkmaktadır. Kültürlerarası etkili bir iletişim ve çok kültürlü bireyler yetiştirmek hedefleniyorsa, o zaman yabancı uyruklu öğrencilerin sahip olduğu farklı cinsiyet, etnik, yaş, ırk, ulus veya dil kimliklerinin tanınması gerekir. Uluslararası öğrenciler, gittikleri eğitim kurumundaki öğretmenlerin genelde öğretim yöntem ve tekniklerini öğrencilerin ihtiyaçları doğrultusunda uyarlamaya karşı duyarsız kaldığını bildirmektedir.

Yabancı uyruklu öğrencilerin olduğu sınıflarda, öğretmenlerin bu öğrencilere karşı duyarsız oldukları durumlarda, yaşanacak kimlik sorunlarının önü açılmaktadır. Bu yüzden, sınırlar arası eğitim deneyimlerinin istenilen sonuçları getirmesi bekleniyorsa, öğrencilerin kişisel ve sosyal kimliklerinin de göz önünde bulundurulması; sadece eğitim kurumlarııı değil, aynı zamanda sosyal ve akademik çevrelerin de bu doğrultuda bilinçlendirilmesi gerekmektedir. Kültürlerarası eğitim ortak bir küresel kimlik sağlayabilir, ancak bunun elde edilebilmesi için öğrencilerin kimlik sorunlarının yakından tespit edilmesi ve bu sorunlara karşılıklı çözümler getirilmesi gerekir.

\section{Amaç}

Bu çalışma, Avrupa'daki değişim programına dahil olan uluslararası öğrencilerin mevcut koşullarını belirleyebilmek üzere ilgili alanyazının detaylı taramasını sunmaktadır. Alanyazın taramasında öğrencilerin karşılaştıkları sorunları belirlerken, özellikle Türk öğrencilerin ev sahibi ülkelerde yaşadıkları kimlik sorunlarını ortaya koymak hedeflenmiştir.

\section{Yöntem}

Çalışmanın amacı doğrultusunda gerçekleştirilen alan yazın taraması, içerik analizi tekniği kullanılarak yapılmışırı (Neuendorf, 2002). Güncel çalışmaların ve ilgili raporların sonuçları, özellikle Türk öğrencilerin yaşadıkları kimlik sorunları odağında incelenerek raporlaştııımıştır. Çalışmada elde edilen sonuçların tartışımasıyla uluslararası öğrencilerin mevcut eğitim ortamlarının iyileştirilmesi çabalarına katkıda bulunmak amaçlanmaktadır. 


\section{Avrupa Ortak Kimliği}

Ortak bir Avrupa kimliği oluşturmak Avrupa Birliği'nin temel amaçlarından birini oluşturmaktadır. Bunun en önemli nedenlerinden biri Avrupa Birliği'nin meşruiyetini güçlendirmektir. Üye ülkeleri tarafından dolaylı olarak meşrulaştırılarak Avrupa Birliği, böylece yasal bir güç kazanmıştır. Ancak, birçok araştırmacı bu dolaylı meşrulaştırmanın tarafından yetersiz olduğunu ifade etmektedir (Decker, 2011; Habermas, 2001; Mather, 2006). Avrupa'nın birleşmesi sadece ekonomik ve yasal geçişlerle mümkün olamazdı. Bu tür bir birleşme, tabandan yukarı doğru ve sosyal etkileşimler sonucu ortaya çıkacak ortak bir Avrupa kimliği yaratarak mümkün olabilirdi. Fakat, araştırmalar teşviklerle gerçekleştirilen sosyal etkileşimlerin zaman ve bağlam açısından sınırlı kalacağını (örneğin turistik geziler veya iş seyahatleri) ve istenilen bütünleşme için yeterli olanaklar sağlayamayacağını göstermektedir (Feldstein, 1967; Puchala, 1981). Sosyal iletişim, sosyal etkileşimler için bir ağ oluşturmakta ve kültürlerarası farkındalık ve hoşgörüyü artırmakta olsa da, ortak bir sosyal kimlik oluşturulması ile sonuçlanması beklenemez. Bu duruma Feldstein (1967), 1960'larda Avrupa'ya göç eden sayısız işçi göçmenlerini örnek olarak gösterir. Bu göçmenlerin ev sahibi ülkede yaşayıp çalışmalarına ve her türlü sosyal etkileşimde bulunmalarına rağmen bir Avrupa kimliği edinmiş olmalarından söz etmek zordur. Çoğu göçmen, beklenenin tam aksine, kendi grubu içinde kalarak daha kapalı bir aile hayatı kurmuş ve ev sahibi ülkenin kültüründen uzak durarak tam bir bütünleşmeye direnç gösteren bir tutum sergilemiştir. Bu durum da bize, ortak bir sosyal kimlik oluşturma sürecinin sadece sosyal veya ekonomik ya da akademik etkileşimler sonucu kendiliğinden ortaya çıkamayacağını göstermektedir. Çünkü 'kimlik' durağan ya da katı bir kavramdan ziyade, çok katmanlı, çok boyutlu ve sürekli değişen bir yapıya sahiptir.

Üniversite Öğrencilerinin Hareketliliği için Avrupa Topluluğu Eylem Planı (Erasmus) programı Avrupa'daki en kapsamlı değişim programıdır ve kuruluş nedenlerinden biri ortak bir Avrupa kimliği oluşturmaktır. 1987'de Avrupa Birliği tarafından başlatılan bu programla, iki milyonun üstünde öğrenci Avrupa'da yabancı bir ülkede eğitim görerek Avrupa ülkelerinin kültürlerini yakından deneyimleme şansına sahip olmuştur. Üniversite öğrencileri için bir değişim programı olarak geliştirilen bu program, Avrupa Birliği tarafından organize edilip finansal olarak desteklenmektedir. Ayrıca, Avrupa Adalet Divanı diploma denkliğini sağlayan düzenlemeler ile öğrenci harç ücretlerinde iyileştirmelere gidilmesini sağlamıştır (Sigalas, 2009). 1995'te, Erasmus programı Sokrates adı altında diğer uluslararası eğitim programları ile birleştirilmiştir (European Press Releases, 2006). Erasmus 'Yaşam Boyu Öğrenme' programının bir parçası olarak, 27 Avrupa Birliği üye ülkesi ile Türkiye, Norveç, İzlanda ve Lihtenştayn gibi ülkeler arasında üç milyonun üzerinde öğrencinin yurtdışında eğitim almasını desteklemektedir Liechtenstein (European Press Releases, 2006). Yaşam Boyu Öğrenme programı kapsamında, 2007'den bu yana, okullar için Comenius, yüksek öğrenim için Erasmus, yüksekokullar ile staj eğitimi programları için Leonardo da Vinci, ve yetişkin eğitimi için Gruntvig programları ile yurtdışı eğitimleri koordine etmektedir (Avrupa Komisyonu, 2007). Bugün, Yaşam Boyu Öğrenme programı yeni Erasmus Plus 20142020 programı altında yürütülmektedir. Bu programa dahil olabilen ülkeler; 27 üye ülke, Avrupa Ekonomik Alanı/Avrupa Serbest Ticaret Birliği üye ülkeleri, Türkiye, Hırvatistan ve Makedonya'dır. Bu programla getirilen yapısal değişiklikler haricinde, programın amaçları ve genel çerçevesi 1987 Avrupa Birliği Komisyonu kararı ile aynıdır:

Erasmus programının amaçları şunlardır: (i) diğer üye ülkelerde eğitim gören öğrenci sayısında artış ...üye ülkelerde birinci elden edinilen deneyimlerle bu ülkelerin gereksinim duyduğu insan gücünü sağlama... ; (iv) üye ülkeler arasındaki iletişimi güçlendirerek Halklar Avrupası kavramı oluşturmak; (v) mezunların topluluk içinde doğrudan işbirliği deneyimi kazanmasını sağlamak ve böylece topluluk düzeyinde sosyal ve ekonomik sektörlerin yoğun işbirliğinde bulunabilmeleri için gerekli zemini oluşturmaktır (European Press Releases, 2006).

Erasmus programının nihai hedefi, genç nesillerin birbirleriyle sosyal etkileşimlerini arttırmaya destek olarak uluslar üstü bir Avrupa kimliği oluşturmayı sağlamaktır. Avrupa birliği Komisyonu, tabandan başlayarak sınırlar arası sosyal, kişisel ve akademik iletişime olanak sağlayarak Avrupa kimliğini aşılamayı hedeflemiş; ancak, Erasmus değişim programından faydalanan öğrencilerle yapılan çalışmalar bu 
öğrencilerin ciddi sosyal ve akademik sorunlar yaşadığını ortaya koymaktadır. Bu tür sorunların nihai amaç olan ortak kimlik oluşturma sürecini olumsuz etkileyebileceğini söylemek mümkündür.

\section{Değişim Programından Faydalanan Öğrencilerin Yaşadığı Kimlik Sorunları}

Sosyal kimlik, Tajfel'in $(1978$, s.63) ortaya koyduğu en geniş tanımıyla: "sosyal bir grubun (veya grupların) bir üyesi olduğunun, bu üyeliğin değerinin ve duygusal öneminin farkında olan bireyin benlik kavramının bir parçası". Kimlik yapılanmasını ve değişimini anlayabilmek için, kimliğin karmaşık katmanlarının incelenmesi gerekir. Sosyal psikoloji alanında yapılan teorik tartışmalar, sayısız tanımlamalar ve incelemeler bize bireysel kimlik ve sosyal kimliğin bu katmanlar arasında olduğunu göstermektedir. Tajfel'e (1981) göre bireysel kimlik, tüm psikolojik özelliklerin bireysel bir eşsizlik oluşturmak üzere bir araya gelmesiyle oluşmaktadır. ilk başta içgüdülerden beslenerek ortaya çıkan bireysel kimlik, aile ile başlayan daha sonra bireyin yaşadığı toplumun sosyal, politik, tarihsel, kültürel ve dilsel etmenleriyle şekillenen bir yapılanma sürecine girer (Hurtado \& Silva, 2008). Bu etmenlerin etkileşimi sonucunda birey bir 'benlik kavramı' oluşturur. Bu içgüdüleri nedeniyle bireye özgü ama aynı zamanda insana dair evrensel süreçleri de içine alan bir kavram olarak karşımıza çıkar.

Erasmus programı sadece öğrencilerin farklı ülkelerde eğitim alması amacını taşımamaktadır. Programın amaçları içinde Avrupa ülkelerinin entegrasyonunu desteklemek ve yeni nesillerde ortak bir Avrupa kimliği oluşmasına katkıda bulunmak da vardır. Ancak, araştırmacılar, kimlik kavramının basite indirgenmemesi gerektiğini ve kimlik oluşum sürecinin birçok farklı etmenlerin etkili olduğu katmanlı bir yapılanma olarak ele almamız gerektiği konusunda bizi uyarmaktadırlar (Green, 2007; Marks, 1999). Değişim programlarındaki öğrenciler üzerine yapılan çalışmaların bulguları ile bu konuda sunulmuş raporların sonuçları, yeni bir kimlik oluşum sürecinin karmaşıklı̆̆ından bahsederken; değişim programından faydalanan öğrencilerin yaşadıkları sorunların bu süreci olumsuz etkileyeceği konusunda uyarılar getirmektedir. Bu sorunlardan biri, ev sahibi ülkedeki sosyal ortama uyum gösteremeyen öğrencilerin gittikleri ülkede yaşadıkları kimlik karmaşasıdır (Kim, 2001; Ward, 2004). Sosyal uyum veya bütünleşmenin nedenleri; yaşanan ekonomik zorluklar (Yücesin-Taş, 2013); yabancı dil eksikliği (Groux \& Porcher, 2000); öz güven eksikliği (Brown, 2008; Giddens, 1991); veya ev sahibi ülkenin sosyal ortamındaki tepki ya da ayrımclık (Brown, 2009; Stephan \& Stephan, 2001) olabilir. Araştırmacılar bu noktada, makro/evrensel boyutta yaşanan jeopolitik gerilimlerin mikro düzeyde küçük çevrelerde yaratacağı olumsuz etkilerin göz önünde bulundurulması gerektiğini vurgulamaktadır (Althen, 1994; Brown, 2009; Giddins, 1991; Ward, 2004). Günümüzde yaşanan devletlerarası sosyal-politik sorunların mikro düzeyde de etkileri bilinmektedir. Örneğin, 11 Eylül'de Amerika'da yaşanan terör saldırısı, batı ülkeleri arasında 'islamafobi'yi tırmandırmış ve bunun sonuçlarından biri olarak Irkçıı ve Hoşgörüsüzlüğe Karşı Avrupa Komisyonu 2010 raporunun kaydettiğine göre, Müslüman ülkelerden gelen değişim programı öğrencilerine karşı olumsuz tutumlarda artış gözlenmiştir. Brown (2009), İngiltere'de Müslüman ülkelerden gelen değişim programı öğrencilerine karşı saldırıların artıı̆ını ifade etmiştir. Benzer şekilde, Amerika'da Müslüman ülkelerden gelen öğrencilere karşı önyargılar ve ayrımcılıktan dolayı, uluslararası öğrenci sayısında düşme eğilimi kaydedilmektedir (Lee \& Rice, 2007).

Türk öğrencilerin Erasmus programı ile gerçekleştirdikleri yurtdışı eğitim deneyimlerini konu alan çalışmalar, çoğunlukla öğrencilerin karşılaştıkları akademik veya dil ile ilgili problemlere odaklanmıştır (Aba, 2013; Bakioglu \& Certel, 2010; Duru \& Poyrazli, 2007; Işık, 2011, Kaypak \& Ortactepe, 2014). Sayısı sınırlı olmakla beraber, Erasmus programının Türk öğrenciler üzerindeki kültürel veya kişisel etkilerine odaklanan çalışmalar çoğunlukla kültürel uyum (Penbek, Yurdakul, \& Cerit 2012) veya tutum ya da kimlik ile ilgili sorunlar yaşadığını ortaya koymaktadır (Başaran, 2010; Cısdık, 2014; Ersoy \& Günel, 2011; Şahin, 2008). Ev sahibi ülke mensuplarının sosyal iletişimde isteksiz olması (Cısdık, 2014), öğretmenlerin değişim programı öğrencilerine karşı tutumları (Başaran, 2010) ve bu öğrencilere karşı kültürel önyargılı tutumlar (Endes, 2015; Yıldırım \& İlin, 2013) bu sorunlar arasındadır. Türk öğrencilerin değişim programları aracılığı ile yabancı ülkelerde eğitim almaya Avrupa kültürünü daha yakından tanımak yerine daha çok bu programlara karşı araçsal motivasyona sahip olmalarına neden olmaktadır. Yıldııım ve ilin'e (2013, s. 119) göre, Türk öğrencilerin gittikleri ülkelerde karşılaştıkları kültürel önyargılarla sürekli mücadele etmek zorunda kaldıklarını ve bundan dolayı öğrencilerin 'psikolojik sağlığı'nın tehdit altında 
kalabildiğini ifade etmektedir. Endes (2015), Erasmus programına katılan Türk öğrencilerin karşılaştıkları hem akademik hem de kişisel ve sosyal sorunları araştırmıştır. Çalışmanın sonuçlarına göre, katılımcı öğrencilerin yarıdan fazlası gittikleri ülkelerde uyum sorunu yaşamadığını ifade ederken, az sayılmayacak bir grup ise (33 \%) bu tür uyum sorunları yaşadığını bildirmiştir. Öğrencilerin ifadelerine göre, gittikleri ülkelerde maruz kaldıkları olumsuz tutum ve ayrımcılık uyum süreçlerini olumsuz yönde etkilemiştir. Öğrenciler, ev sahibi ülkede dini bakış açılarının bazı çalışanların tutumlarını olumsuz yönde etkilediğini ve bunun sonucunda kendilerini önemsiz ya da saygı gösterilmeyen kişiler olarak hissettiklerini bildirmişlerdir. Endes'in (2015) ifadesiyle, “...bazı akademik personel ve öğretmenler ders sırasında Erasmus öğrencilerine kültürel önyargı ile yaklaşmakta, olumsuz davranışlar gösterebilmektedir" (s.1413). Avrupa'da Erasmus programıyla bulunan Türk öğrencilerin kültürel bütünleşme üzerine odaklanan bir diğer çalışma sonuçlarına göre, Avrupa'lı öğrencilerin Türkiye'den gelen uluslararası öğrencilere karşı ilk değerlendirmelerinin genelde olumsuz olduğu bildirilmektedir (Kagitcibasi, KisbuSakarya, \&Aydogdu, 2017). Çalışmada bu olumsuz değerlendirmenin nedenleri araştıııımamış olsa da, yazarlar her iki ülke öğrencilerinin bilgilendirilmesi ve desteklenmesi için oryantasyon programlarının gereğine dikkat çekerek bu programların olumlu kültürel iletişim olanaklarını arttıracağını ve kültür çatışmalarından kaynaklı sorunları engelleyeceğini vurgulamaktadır.

Avrupa'daki değişim programları kapsamındaki yabancı uyruklu öğrencilerin ortak bir Avrupa kimliği oluşturabilmeleri için gruplar arası iletişim olanaklarının açık olması gerekmektedir. Eğer bu öğrenciler, gittikleri ülkelerde uluslarına ya da kültürlerine karşı saldırılara maruz kalırlarsa, sonuç genellikle kendilerini ülkelerinin 'doğal temsilcisi' olarak görmelerine ve hoşgörü ve iletişim kurmaya daha az yatkın olmalarına yol açabilmektedir (Ward, 2004). Brown ve Aktaş (2012), bir kimliğin bir saldırı görmesi durumunda önem kazanacağını ancak "aitlik düşüncesinin" doğal olarak ortaya çıkması durumunda kimlik ile ilgili bir savunmaya veya korumaya gerek kalmayacağı için kimlik üzerine çok fazla düşünülmeyeceğini öne sürmektedir (s.5). Branscombe ve Wann (1994), saldırıya uğraması durumunda kültürel kimliğin güçlü bir direnç oluşturacağını ve birey ile diğer grup arasındaki etkileşimi olumsuz etkileyerek olası bir hoşgörü ve yakınlaşmanın zarar göreceğini vurgulamaktadır. Bu yüzden, değişim programları ile başka ülkelerde eğitim almak için bulunan öğrencilerin kimlik konusunda yaşadıkları sorunların önemle ele alınması ve bu konuda ortaya çıkabilecek problemlere önlemler geliştirilmesi gerekmektedir.

\section{Tartışma ve Sonuç}

2008 Avrupa Komisyonu Eğitim ve Öğretim Dairesi raporuna göre Avrupa'da eğitim amaçlı seyahatlerde hala artış vardır. Değişim programlarına talepteki bu artı̧̧ ev sahibi ülkelere birçok yararların (Andrade, 2006) yanında belli sorunları da (Fligstein, 2008; Risse, 2010) beraberinde getirmektedir. Sayısal olarak kaydedilen bu artış, Erasmus değişim programının nicelik açısından hedeflerine yaklaştığını gösterse de; kültürel farkındalı̆ı̆ artması, kişisel ve mesleki anlamda serbest seyahat imkânları, Avrupa'da 'biz' kavramının benimsenmesi gibi niteliksel amaçlara henüz ulaşıldığı bildirilememektedir. Değişim programlarından yararlanan Türk öğrenciler ele alındığında, bildirilen problemler arasında yabancı dil yetersizliği, akademik uyumda zorluk, sosyal ve kültürel uyumda zorluklar ile ev sahibi ülkedeki genel olarak olumsuz tutum ve davranışlardan kaynaklanan kimlik sorunları yer almaktadır (Cetinkaya-Yildiz, Cakir \& Kondakcı, 2011; Endes, 2015; Isık, 2011).

Bu gibi nitel hedeflerin gerçekleştirilmesi, genç nesillerin kültürlerarası etkileşime istekli olmaları ve diğer kültürler hakkında olumlu tutumlara sahip olmalarıyla gerçekleştirilebilir. Yabancı bir ülkede yaşama deneyimi bu tür tutumların gelişmesi için gerekli çevreyi fiziksel olarak sağlarken, sosyal veya politik çevreden kaynaklanan olumsuz etmenler bu tutumların olumsuz yönde gelişmesine neden olabilir. Bu yüzden, PLOTEUS (Avrupa'da Eğitim Fırsatları Portalı) gibi programların örnek alınarak arttııılması ve değişim öğrencilerinin akademik zorluklarının yanında, kişisel ve sosyal sorunlarıyla da yakından ilgilenilmesi gerekmektedir. Akademik, sosyal ve bireysel açılardan olumlu bir deneyime sahip nesiller hedeflenen hoşgörülü ve kültürlerarası iletişimde etkin bireyler olabileceklerdir.

Kültürlerarası farkındalığın arttıııması için tüm tarafların ortak çözümler üretmesi son derece önemlidir. Bu çözüm ortaklığının sadece ev sahibi ülkeleri değil, her iki ülkenin eğitim kurumlarını, 
idarecilerini, öğrencilerini, değişim programı yöneticilerini ve koordinatörlerini, öğretmenleri, yerel vatandaşlarını ve idari otoritelerini de içine alması gerekir. Bu bağlamda, Erasmus Koordinasyon Ofislerinin, öğrencilerin hem akademik sürecini yakından takip etmek hem de onların kişisel ve manevi durumlarından haberdar olabilmek için ev sahibi ülkelerdeki ofisler ve akademik personel ile sürekli iletişim içinde olması gerekmektedir. Ancak, Endes'in de (2015) ifade ettiği gibi, böyle bir iletişim talebi ev sahibi ülkedeki yetkililerce kabul edilmediği veya iletişime rağmen öğrencilere karşı olumsuz tutumların devam ettiği durumlarda, bu kurum ile daha sonraki yıllarda yapılacak uluslararası değişim antlaşmalarının yeniden gözden geçirilmesi önerilmektedir. Öğrencilerin yabancı bir ülkeye eğitim almaya gitmelerinden önce, onlara bu ülkeye ve küresel kültürel bakış açısına dair bir uyum eğitimi bu çözümler arasında olabilir. Diğer ülkelere giden Türk öğrenciler için geliştirilecek oryantasyon programı, öğrencileri gidecekleri ülkenin akademik ve kurumsal süreçleri hakkında bilgilendirirken, herhangi bir sorun ihtimalinde dile getirebilmeleri ve tartışma gerçekleştirebilmeleri için gerekli iletişim becerilerini geliştirmeye yardımcı olmalıdır. Öğrencilerin kendi haklarını ve sorumluluklarını bilmeleri ve bunları ifade edebilmeleri durumunda daha sağlıklı iletişim kurabilecek ve karşılıklı anlaşmanın (Aba, 2016) ve sorun çözümünün anahtarı olan kültürel yeterlilik geliştirebileceklerdir. Bu doğrultuda hazırlanacak oryantasyonprogmanları, ev bakımı ya da alışveriş gibi gidilecek ülkedeki günlük rutinler hakkında bilgi de içerirse, giden öğrencilerin günlük stresleri azaltılabilecektir (Cetinkaya-Yildiz, Cakir\&Kondakcı, 2011). $\mathrm{Bu}$ tür eğitimlerin sadece öğrencilerle sınırlı kalmayıp, her iki ülkenin eğitimcilerini ve program yöneticilerini de kapsaması daha kapsamlı bir etki sağlayabilir. Bu eğitimler dijital ortamlarda sunularak maliyeti azaltılabilir ve daha geniş kesimlere ulaşılması sağlanabilir. E-posta, elektronik mesajlar, sosyal medya, dijital yayınlar veya dijital platformlar her iki ülkenin tarihi, değerleri, normları, gelenekleri, eğitim sistemleri ve ilgili başka konularda tarafları bilgilendirecek bu tür eğitimleri vermek için kullanılabilir. Değişim programı anlaşması olan ülkelerin temsilcilerinin seminerler veya sempozyumlar yoluyla bir araya gelerek öğrencileri ve kültürleri ile ilgili karşılıklı diyaloglar geliştirmeleri de sürece katkı sağlayabilir. Her iki ülke iletişime açık ve esnek olabiliyor ve olumlu ilişkiler kurabiliyorsa, o zaman güçlü bir Avrupa ortak kimliği oluşturma ve sağlıklı bir kültürlerarası etkileşim oluşturma mümkün olabilir.

\section{Bilgilendirme}

Bu çalışmanın İngilizce sürümü 2. Uluslararası Akademik Araştırmalar Kongresi'nde sunulmuş ve INES Kongre Özet Kitabında özeti yayınlanmıştır. 


\section{References}

Aba, D. (2013). Internationalization of higher education and student mobility in Europe and the case of Turkey. Cukurova University Faculty of Education Journal, 42, 99-111.

Aba, D. (2016). Addressing intercultural experience and academic mobility in higher education. Journal of Intercultural Communication Research, 45(6), 487-502.

Alesina, A. and Fuchs-Schundeln, N. (2005). Goodbye Lenin (or not?): The Effect of Communism on People. HarwardIntitute of Economic Research, Cambridge, America: Harward University Press.

Althen, G. (1994). Recurring issues in intercultural communication. In G. Althen (Ed.), Learning across Cultures (pp. 189-190). Washington, DC: NAFSA.

Andrade, M. S. (2006). International students in English-speaking universities. Journal of Research in International Education, 5(2), 131-154.

Bakioglu, A., \&Certel, S. S. (2010). Erasmus programina katilan öğrencilerin akademik yaşantilarinin nitel olarak incelenmesi [A qualitative investigation of Erasmus students' academic lives]. Avrupa Arastirmalari Dergisi, 18, 37-62.

Başaran, S. (2010). Effects of podcasts on language learning beliefs and self-efficacy perceptions of firstyear Turkish university students, Doctorate Dissertation [internet yayınlarınınbirincisınıfTürköğrencilerinindilöğrenmeveyeterlilikalgılarınaetkisi]. Çukurova University, Adana, Turkey.

Branscombe, N. \& Wann, D., (1994). Collective self-esteem consequences of outgroup derogation when a valued social identity is on trial. European Journal of Social Psychology, 24 (6), 641-657.

Brown, L. (2008). The adjustment journey of international postgraduate students at a university in England: An ethnography [ingiltere'deyükseköğrenimgörenuluslararasıöğrencilerinuyumsüreci: Biretnografiçalışması]. Doctorate Dissertation, Bournemouth University, UK.

Brown, L. (2009). A failure of communication on the cross-cultural campus. Journal of Studies in International Education, 13(4), 439-454.

Brown, L. \& Aktas, G. (2012). Turkish university students' hopes and fears about travel to the west. Journal of Research in International Education, 11(1), 3-18.

Carr, S. C., Mckay, D. \& Rugimbanar, S. C. (1999). Managing Australia's aid- and self-funded international students. International Journal of Education Management, 13(4), 167-172.

Cetinkaya-Yildiz, E., Cakir, S. G. \& Kondakci, Y. (2011). Psychological distress among international students in Turkey. International Journal of Intercultural Relations, 35, 534-539.

Cisdık, Z. K. (2014) Exploring the changes in Turkish university students' language learning beliefs as a result of 'Erasmus student mobility for studies programme' [Erasmus değişimprogramısonrasındaTürküniversiteöğrencilerinindilöğrenmealgılarındakideğişimlerinincelenm esi]. M.A. Thesis, Cukurova University, Adana, Turkey.

Colebatch, T. (2005). Foreign students settle. Retrieved from http://www.theage.com.au /news/Immigration/ Foreign-students- settle/2005/01/21/ 1106110942999.html [Accessed: 01.12.2008].

Coley, M. (2005). The English language entry requirements of Australian universities for students of nonEnglish speaking background. Higher Education Research \& Development, 18(1), 7-17.

Decker, F. (2011). Governance beyond the nation-state. Reflections on the democratic deficit of the European Union. Journal of European Public Policy, 9, 256-272.

Duru, E., \&Poyrazli, S. (2007). Personality dimensions, psychological-demographic variables, and English language competency in predicting level of acculturative stress among Turkish international students. International Journal of Stress Management, 14(1), 99-110. 
Meral ŞEKER- Çukurova Üniversitesi Eğitim Fakültesi Dergisi, 47(1), 2018, 109-125

Endes, Y. Z. (2015). Overseas education process of outgoing students within the Erasmus Exchange Programme. Procedia - Social and Behavioral Sciences, 174, 1408-1414.

Ersoy, A., \&Günel, E. (2011). Cross-cultural experiences through Erasmus: Pre-service teachers' individual and professional development. Eurasian Journal of Educational Research, 42, 63-78.

Europa Press Releases (2006). Erasmus @ 20: the Commission launches the celebrations for the anniversary of its flagship programme. Retrieved from: http://europa.eu/rapid/press-release IP-061698 en.htm?locale=en [Accessed: 17.07.2017].

European Commission, (2006). Putting knowledge into practice: A broad-based innovation strategy for the EU. Retrieved from http://eur-lex.europa.eu/LexUriServ/site/en/com/2006/ com2006_0502en01.pdf [Accessed: 11.04.2014].

European Commission, (2007). Report from the Commission to the Council on the Council Resolution of 23 November 2007 on modernizing universities for Europe's competitiveness in a global knowledge economy. Retrieved from http://ec.europa.eu/education/ higher-education/doc/com/680_en.pdf [Accessed: 18.11.2014].

European Commission against Racism and Intolerance, (2010). ECRI report on the United Kingdom. Retrieved from http://www.coe.int/t/dghl/monitoring/ecri/Country-bycountry/United_Kingdom/GBR-CbC-IV-2010-004-ENG.pdf [Accessed: 18.11.2014].

Feldstein, H. (1967). A study of transaction and political integration: transnational labour flow within the European Economic Community. Journal of Common Market Studies, 6, 24-55.

Fichte, J. G. (1968). Addresses to the German Nation. New York: Harper.

Fligstein, N. (2008). Euroclash: The EU, European identity and the future of Europe. England: Oxford University Press.

Giddens, A. (1991). Modernity and self-identity: Self and Society in the late modern age. Cambridge: Cambridge University Press.

Green, D. M. (2007). The Europeans: political identity in an emerging polity. London: Lynn Riennier, Boulder.

Groux D \& etPorcher L. (2000). Les echangeseducatifs [Educational exchanges]. Paris: L'Harmattan.

Habermas, J. (2001). Why Europe needs a constitution. New Left Review, 11, 5-18.

Ho, L. C. (2009). Global multicultural citizenship education: A Singapore experience. The Social Studies, 100 (6), 285-293.

Hurtado, A. \& Silva, J. M. (2008). Creating new social identities in children through critical multicultural media: The case of Little Bill. New Directions for Child and Adolescent Development, 120, 17-30.

Isik, A. (2011). Language education and ELT materials in Turkey from the path dependence perspective. Hacettepe University Journal of Education, 40, 256-266.

Jacob, E. J. \& Greggo, J. W. (2001). Using counselor training and collaborative programming strategies in working with international students. Journal of Multicultural Counseling and Development, 29(1), 7388.

Kagitcibasi, C., Kisbu-Sakarya, Y. \& Aydogdu, E. (2017). Intercultural engagement and relatedness: Examining mediation effects. International Journal of Intercultural Relations, 61, 21-28.

Kaypak, E. \& Ortactepe, D. (2014). Language learner beliefs and study abroad: A study on English as a lingua franca (ELF). System, 42, 355-367.

Kim, H. Y. (2001). Becoming intercultural: An integrative theory of communication and cross-cultural adaptation. CA: Thousand Oaks.

Kim, H. Y. (2001). Learner investment, identity, and resistance to second language pragmatic norms. System, 45, 92-102. 
Kuhn, T. (2012). Europa ante Portas: Border residence, transnational Interaction and Euroscepticism in Germany and France. European Union Politics, 13(1). 94-117.

Lee, D. (1997). What teachers can do to relieve problems identified by international students? New Directions for Teaching and Learning, 70, 93-100.

Lee, J. J., \& Rice, C. (2007). Welcome to America?: International student perceptions of discrimination. Higher Education, 53, 381-409.

Lewthwaite, M. (1996). A study of international students' perspectives on cross-cultural adaptation. International Journal for the Advancement of Counselling, 19(2), 167-185.

Marks, G. (1999). Territorial identities in the European Union. Oxford: Oxford University Press.

Marshall, E. (2005). Cash-short schools aim to raise fees, recruit foreign students. Science, 307 (5710), 656.

Mather, J. (2006). Legitimating the European Union: Aspirations, inputs and performance. New York: Palgrave MacMillan.

NAFSA (Association of International Educators) (2003). In America's interest: Welcoming international students. Report of the strategic task force on international student access, Retrieved from http://www.nafsa.org/content/ PublicPolicy/stf/stf.htm, [Accessed 26.11. 2014].

Neuendorf, K. (2002). The content analysis guide book. California: Sage Publications Inc.

Penbek, S., Yurdakul, D., \&Cerit, A. G. (2012). Intercultural communication competence: A study about the intercultural sensitivity of university students based on their education and international experiences. International Journal of Logistics Systems and Management, 11, 232-252.

Peterson, D.M., Briggs, P., Dreasher, L., Horner, D. D. \& Nelson, T. (1999). Contributions of international students and programs to campus diversity. New Directions for Student Services, 86, 67-77.

Puchala, D. (1981). Integration theory and the study of international relations. In Merrit, R.L. and Russett, B.M. (eds.), From National Development to Global Community. Essays in Honor of Karl W. Deutsch (pp. 145-163). London: George Allen \& Unwin.

Ramburuth, P. (2001). Language diversity and the first-year experience: Implications for academic achievement and language skills acquisition. Journal of the First-Year Experience, 19(2).75-93.

Ramsay, S., Barker, M. \& Jones, E. (1999). Academic adjustment and learning processes: A comparison of international and local students in first-year university. Higher Education Research \& Development, 18(1), 129-144.

Reisner, E. (1922). Nationalism and education since 1789. New York: Macmillan.

Risse, T. (2010). A community of Europeans? Transnational identities and public spheres. New York: Ithaca.

Robertson, M., Line, M., Jones, S. \& Thomas, S. (2000). International students, learning environments and perceptions: A case study using the Delphi technique. Higher Education Research \& Development, 19(1), 89-102.

Şahin, M. (2008). Cross-cultural experience in preservice teacher education. Teaching and Teacher Education, 24 (7), 1777-1790.

Sarkodie-Mensah, K. (1998). International students in the US: Trends, cultural adjustments, and solutions for a better experience. International Library Education, 39(3), 214-222.

Schneider, M. (2000). Others' open doors. How other nations attract international students: Implications for US educational Exchange. Retrieved from http://exchanges.state.gov/iep/execsummary.pdf [Accessed 01.12.2005].

Sigalas, E. (2009). Does ERASMUS student mobility promote a European Identity? Constitutionalism WebPapers, 2. Retrieved from https://www.wiso.uni-hamburg.de/fachbereichsowi/professuren/wiener/dokumente/conwebpaperspdfs/2009/conweb-2-2009.pdf 
Meral ŞEKER- Çukurova Üniversitesi Eğitim Fakültesi Dergisi, 47(1), 2018, 109-125

Stephan, W. \& Stephan, C. (2001). Improving intergroup relations. New York: Thousand Oaks.

Tajfel, H. (1978). Differentiation between social groups: Studies in the social psychology of intergroup relations. New York: Penguin Books.

Tajfel, H. (1981). Human groups and social categories: Studies in social psychology. Cambridge: Cambridge University Press.

Tompson, H. B. \& Tompson, G. H. (1996). Confronting diversity issues in the classroom with strategies to improve satisfaction and retention of international students. Journal of Education for Business, 72(1), 53-57.

Trice, A. (2003). Faculty perceptions of graduate international students: The benefits and challenges. Journal of Studies in International Education, 7(4), 379-403.

UNESCO, (2014). Unesco Institute for Statistics: Global flow of tertiary-level students. Retrieved from http://www.uis.unesco.org/Education/Pages/international-student-flow-viz.aspx, [Accessed: 03.11.2014].

Ward, C. (2004). Psychological theories of culture contact and their implications for intercultural training. In D. Landis, J. Bennett \& M. Bennett (Eds.), Handbook of intercultural training (3rd ed.). Thousand Oaks, CA: Sage.

Weber, E. (1976). Peasants into Frenchmen: The modernization of rural France: 1870-1914. Stanford, CA: Sage Publishing.

Yildirim, R. \& Ilin, G. (2013). Some Reflections on Cultural Adaptation of Turkish Erasmus Students of ELT Department. C.U. Faculty of Education Journal, 42(2), 111-121.

Yucesin-Tas, Y. T. (2013). Problems encountered by students who went abroad as part of the Erasmus Programme and suggestions for solutions. Journal of Instructional Psychology, 4O(3), 81-87.

Zhao, C. M., Kuh, G. D. \&Carini, R. M. (2005). A comparison of international students and American student engagement in effective educational practices. Journal of Higher Education, 76(2), 209-231. 